\title{
Breaking Bad News Training Program Based on Video Reviews and SPIKES Strategy: What do Perinatology Residents Think about It?
}

\section{Programa de treinamento para comunicação de más notícias baseado em revisão de vídeos e na estratégia SPIKES: o que pensam os residentes de perinatologia?}

\author{
Maria Silvia Vellutini Setubal ${ }^{1}$ Andrea Vasconcelos Gonçalves ${ }^{1}$ Sheyla Ribeiro Rocha ${ }^{1}$ \\ Eliana Martorano Amaral ${ }^{1}$ \\ ${ }^{1}$ Faculdade de Ciências Médicas, Universidade Estadual de Campinas \\ (Unicamp), Campinas, SP, Brazil \\ Address for correspondence Maria Silvia Vellutini Setubal, PhD, \\ Rua Dr. Alexander Fleming, 101, CEP 13083 Campinas, SP, Brazil \\ Rev Bras Ginecol Obstet 2017;39:552-559. \\ (e-mail: silviavsetubal@gmail.com).
}

\begin{abstract}
Keywords

- health communication

- simulation training

- program evaluation

- qualitative analysis

Objective Resident doctors usually face the task to communicate bad news in perinatology without any formal training. The impact on parents can be disastrous. The objective of this paper is to analyze the perception of residents regarding a training program in communicating bad news in perinatology based on video reviews and setting, perception, invitation, knowledge, emotion, and summary (SPIKES) strategy. Methods We performed the analysis of complementary data collected from participants in a randomized controlled intervention study to evaluate the efficacy of a training program on improving residents' skills to communicate bad news. Data were collected using a Likert scale. Through a thematic content analysis we tried to to apprehend the meanings, feelings and experiences expressed by resident doctors in their comments as a response to an open-ended question. Half of the group received training, consisting of discussions of video reviews of participants' simulated encounters communicating a perinatal loss to a "mother" based on the SPIKES strategy. We also offered training sessions to the control group after they completed participation. Twenty-eight residents who were randomized to intervention and 16 from the control group received training. Twenty written comments were analyzed.

Results The majority of the residents evaluated training highly as an education activity to help increase knowledge, ability and understanding about breaking bad news in perinatology. Three big categories emerged from residents' comments: SPIKES training effects; bad news communication in medical training; and doctors' feelings and relationship with patients.

Conclusions Residents took SPIKES training as a guide to systematize the communication of bad news and to amplify perceptions of the emotional needs of the patients. They suggested the insertion of a similar training in their residency programs curricula.
\end{abstract}

received

April 20, 2017

accepted

June 5, 2017

published online

August 4, 2017
Copyright @ 2017 by Thieme Revinter

Publicações Ltda, Rio de Janeiro, Brazil
License terms

c) $(1) \$$ 10.1055/s-0037-1604490. ISSN $0100-7203$. 


\section{Resumo}

\section{Descritores \\ - comunicação em saúde \\ - treinamento com simulação \\ - avaliação de programa \\ - análise qualitativa}

Objetivo Médicos residentes, em geral, enfrentam a tarefa de comunicar más notícias em perinatologia sem um treino formal prévio. $O$ impacto nos pais pode ser desastroso. O objetivo deste artigo é analisar as percepções dos residentes sobre um programa de treinamento para a comunicação de más notícias em perinatologia baseado na revisão de vídeos e na estratégia SPIKES.

Métodos Analisamos os dados complementares coletados dos participantes de um estudo de intervenção controlado e aleatorizado que avaliou a eficácia de um programa de treinamento para ampliar as habilidades dos residentes em comunicar más notícias. Os dados foram coletados utilizando um questionário em escala Likert. Através da análise temática de conteúdos buscamos apreender os significados, sentimentos e experiências descritos nos comentários dos residentes em resposta a uma questão aberta avaliando o treinamento. Metade do grupo recebeu treinamento, que consistiu de discussões do vídeo da consulta simulada de cada participante em que ele comunicava uma perda perinatal para uma "mãe" baseado na estratégia SPIKES. Ofereceu-se treinamento também para o grupo controle após encerraram sua participação na pesquisa. Vinte e oito residentes aleatorizados para a intervenção e 16 do grupo controle receberam treinamento. Vinte comentários escritos foram analisados. Resultados A maioria dos residentes avaliou o treinamento como uma ótima atividade educativa para ajudá-los a aumentar conhecimento, habilidades e compreensão sobre o processo de comunicar más notícias em perinatologia. Três grandes categorias emergiram dos comentários: Efeitos do treinamento SPIKES, comunicação de más notícias no treinamento médico; e os sentimentos dos médicos e sua relação com os pacientes.

Conclusão Residentes de perinatologia entenderam o treinamento SPIKES como um guia para sistematizar a comunicação de más notícias e ampliar suas percepções sobre as necessidades emocionais dos pacientes. Eles sugeriram que treinamentos similares fossem inseridos nos currículos dos programas de residência.

\section{Introduction}

Breaking bad news (BBN) to patients and their families is one of the most difficult tasks health professionals can face. ${ }^{1,2}$ The way bad news are communicated has a big impact on everyone involved: recipients, their families and health professionals. $^{1,3,4}$ In perinatology, BBN requires special attention and unique skills due to the high expectations involved in the project of having a child. ${ }^{5,6}$ For health professionals, unexpected situations make the task even more difficult. ${ }^{7,8}$ Bad news transmitted in a sensitive way, with adequate information can favor the psychological recovery of those who suffered a perinatal loss. ${ }^{6}$ For residents in training, developing the skills necessary to their clinical practice would bring self-confidence and satisfaction. ${ }^{9}$

In Brazil, the National Residency Committee for Pediatrics suggests that residents should develop communication skills, with emphasis in helping families to face death and pain. Nevertheless, there is no specifics on how to achieve this. ${ }^{10}$ In obstetrics, no specific recommendation on communication skills exists. In general, residents learn to transmit bad news by observing senior faculty or more experienced colleagues, with little opportunity to discuss the difficulties involved in the task, thus, perpetuating inadequate attitudes or perceptions. ${ }^{11}$ There is the presumption that this ability might develop by itself during their careers. ${ }^{7,12}$

Two recent articles reinforced the need for training that can teach ways to support parents and families dealing with the specificities of perinatal loss by offering individualized and sensitive care. ${ }^{13,14}$ One is a meta-synthesis of qualitative articles about parents' expectations regarding the care they hoped they would receive and that which they actually received at the time of stillbirth diagnosis. These studies described the difficulties, limitations, lack of skills and sensitivity of health professionals when communicating bad news, making the experience even worse for parents. ${ }^{13}$ Another study, in which parents who lost children evaluate the performances of residents in a breaking bad news training, suggested the importance of developing attitudes and practices for dealing with perinatal loss. ${ }^{14}$

The literature shows that communication skills can be learned and should be taught. Specific training in BBN can be effective in preventing emotional stress for both patients and health professionals. ${ }^{9,15,16}$ One training strategy 
developed by oncologists to communicate difficult news is utilized in many medical specialties; ${ }^{15,17}$ it is called SPIKES and it consists of a plan of action in stages, whose acronym corresponds to the words: 1) Setting for a private place, where the patient can feel comfortable and respected in his/her needs, with health professionals available, allocating plenty of time to the task without interruptions; 2) Perception of the level of patient's understanding of the situation, listening to patient's expectations, anxiety and fears comprehending his/ her position regarding diagnosis, risks and treatment; 3) Invitation for the patient to receive bad news, trying to measure what he/she wants to learn and in which level, adjusting to his/her expectations; 4) Knowledge or to share information about the problem with sensitivity, using lay language easy to understand, with pauses to verify understanding, leaving room for questioning; 5) Emotion, or being opened to embrace patientś emotional reactions when receiving bad news, recognizing and validating their pain; legitimizing their feelings; and 6) Summary of next steps, or developing a follow up plan or strategy to which the patient agrees. These six stages should help health professionals organize the task of communicating bad news, preventing their own anxiety to get in the way, and being aware of the specific needs of the receivers. $^{18}$

This article describes residents' evaluations and perceptions of a training program on breaking bad news skills in perinatology based on video reviews and SPIKES strategy. We aimed to understand their impressions regarding the training activities and the impact on them.

\section{Methods}

This article is the result of a qualitative analysis of data collected from a training program form on residents' evaluation and perception. This instrument containing open and closed questions (Likert scale) was part of a randomized controlled study to determine the training's efficacy in improving perinatology residents' skills to communicate bad news.

\section{Sample}

The participants were a group of volunteer residents from the $1^{\text {st }}$ to the $4^{\text {th }}$ year from the obstetrics and pediatrics programs at a medical school in São Paulo, Brazil. Data collection occurred between June of 2014 and February of 2015.

The study involved simulated encounters (SEs) in which residents transmitted bad news to a standardized patient (SP) trained to act as a mother; obstetric residents would communicate a stillbirth; pediatric residents, an imminent death of a newborn in the intensive care unit. Residents received feedback from the SP after simulation. The encounters and feedback took place in a laboratory and were video recorded. Before the first encounter (SE1), the residents read and signed the consent form and filled out a brief questionnaire with demographics. The principal investigator (PI), present in every SE, ensured SP standardization, collected all the completed forms and provided support for residents or SP as needed. After SE1, the residents were randomly assigned to either the intervention group (SPIKES training) or to control group (no training), according to their entrance number in the project following a computergenerated list. Afterwards, all residents returned for a second simulated encounter (SE2): the SPIKES group after completing training and the controls after completing SE1. The second simulated encounter followed the path of SE1, with the SP blinded to resident's participation in the SPIKES training. Simulation activities and SPIKES training occurred after residents working hours. SPIKES training was offered to the control group after they ended their participation in the project.

\section{Intervention: SPIKES Training}

The SPIKES training sessions were conducted by the PI, a trained psychologist with vast experience in perinatology. A session could be individual, in pairs or in groups and lasted between $1 \mathrm{~h}$ and $2 \mathrm{~h} 30 \mathrm{~m}$ depending of the number of participants. In the first part, centered on the trainee, the residents were asked to report a previous experience in BBN during medical school or residency, either good or bad. It could be a personal experience or any impacting situation they had observed from colleagues, faculty or staff. Discussions ensued around these experiences, bringing up their difficulties, anxieties and unpreparedness. Next, each stage of the SPIKES model was described in detail and used to bring up awareness about the skills necessary to transmit difficult news as described by Baile et al ${ }^{15}$ adapting it to specifics of perinatology. Parents emotional reactions, such as feelings of incredulity, loneliness, emptiness and the terror of carrying death inside them, as described by Defey et al, ${ }^{19}$ were brought to attention. Their expectations regarding doctor's attitudes were also highlighted, followed by suggestions described in the literature on how to support bereaved parents. ${ }^{4,19,20}$ Lastly, residents watched their own videos at SE1 using SPIKES as a tool to help them better understand their actions, choices of words, body language and the nuances of theirs and the "mother's" reactions. The PI worked as a mediator, as recommended by Hammoud et al, ${ }^{21}$ to facilitate residents' perceptions of their difficulties and strengths. The six stages of the SPIKES model guided the discussions.

\section{Data Collection}

After completion, the residents filled out a Likert scale questionnaire of eight items, rating them from 1 to 5 , with 1 meaning "not at all" and 5 "a lot," evaluating the SPIKES training. The instrument was based on the Drexel Medical School Web OSCE. ${ }^{22}$ At the end of the scale, there was an open-ended question asking residents to write comments regarding their experience with the intervention.

\section{Data Analysis}

We grouped the residents' answers to the Likert questionnaire in three categories (not at all/a little; somewhat; quite a bit/ a great deal) and the percentage distribution was analyzed. A thematic analysis of the comments was conducted to understand the meanings attributed to the experience: their ideas, feelings, behaviors and experiences. ${ }^{23}$ Two researchers (MSS and AVG) read every comment and 
classified the major topics according to the study objectives. In a cross verification, the key ideas were regrouped composing the categories of analysis. External validation was done by medical field researchers involved in qualitative research. The comments were codified using the framework method for health sciences suggested by Gale et $\mathrm{al}^{24}$ and its content paraphrased.

\section{Ethics Approval}

The review board of the institution approved the study (Protocol \#496.794 Dec/17/2013. CAAE 23188813.1.0000.5404)

\section{Results}

Among the 100 residents eligible to participate, 61 (30 from obstetrics and 31 from pediatrics) volunteered in the project and 58 completed all the stages. Of these, 28 were assigned to SPIKES training between SE1 and SE2, 11 from obstetrics and 17 from pediatrics. Sixteen residents from the 30 assigned to control group opted to have SPIKES training after finishing their participation. Nine completed the form. A total of 37 responses were analyzed.

They rated the educational value of the activity highly and believe it would likely change their future practices. A high percentage of residents (between 81 and 100\%) reported perceived improvement in knowledge, ability and understanding in BBN. The items "comfort in breaking bad news" and "comfort in responding to patients' emotions" showed smaller percentages of "quite a bit" and "a lot" answers (51.3\% and $64.9 \%$ respectively) (-Table $\mathbf{1}$ ).

A total of 20 residents ( 16 from SPIKES group and 4 from control group) wrote comments in their SPIKES evaluations. These comments were analyzed. Their ages varied from 25 to 31 years and $3 / 4$ were women. More than half were first year residents. All of them had already participated in prior summative simulations and $3 / 4$ had participated in formative simulations. Only 3 residents of these 20 had had some kind of training on communicating bad news before, and it was during medical school (- Table 2).
The following categories of analysis were defined: 1) SPIKES training effects; 2) Medical education and bad news communication and 3) Doctors' feelings and relationship with the patient.

\section{The Effect of SPIKES Training}

The residents' comments suggest a great receptivity to SPIKES training. They rated the activity highly as an educational and learning opportunity, interesting and rewarding. Some residents mentioned that watching their own video from the SE1 was very helpful. Others praised the SP's acting skills. Only one resident pointed out a negative aspect: the short amount of time allocated to training and suggested that in the future there should be more time for more in-depth discussions.

"I found simulation well taught and well planned. Great actress" (\#20 Ped).

"Watching the video was very constructive (\#27 Ped)

As for the aspects related to the SPIKES method, the residents were unanimous in commenting that the strategy offered a practical support to organize the way doctors express themselves. It helped and oriented them to deal with a delicate moment in their medical careers. Some wrote that the methodology described in a simple way the most important steps to be remembered when delivering bad news. They thought the strategy could change their everyday practice; it worked as a technique which favored the acquisition of specific skills. The majority mentioned that SPIKES systematizes in an efficient way the practice of breaking bad news.

"It is a systematic and efficient way, capable of organizing the way doctors express themselves to patients" (\#25 Ped)

"It helps and guides [us] to deal with a very delicate moment in our careers." (\#7 Obst)

“...and by offering data and objective techniques it makes it easier to achieve the skills." (\# 3 Ped)

Table 1 Rating of the activity by the resident doctors

\begin{tabular}{|l|l|l|l|}
\hline Questions & $\begin{array}{l}\text { Not at all/ } \\
\text { a little }\end{array}$ & Somewhat & $\begin{array}{l}\text { Quite a bit/ } \\
\text { a great deal }\end{array}$ \\
\hline & $\mathbf{n}(\%)$ & $\mathbf{n}(\%)$ & $\mathbf{n}(\%)$ \\
\hline 1) How much did the training increase your knowledge of how to BBN? & $1(2.7)$ & $0(-)$ & $36(97.3)$ \\
\hline 2) How much did the training increase your ability to BBN? & $3(8.1)$ & $4(10.8)$ & $30(81.1)$ \\
\hline 3) How much did the training increase your understanding of how to BBN? & $0(-)$ & $2(5.4)$ & $35(94.6)$ \\
\hline 4) How much did the training increase your comfort level in BBN? & $10(27.1)$ & $8(21.6)$ & $19(51.3)$ \\
\hline $\begin{array}{l}\text { 5) How much did the training increase your comfort in } \\
\text { responding to the patient's emotional reactions? }\end{array}$ & $5(13.5)$ & $8(21.6)$ & $24(64.9)$ \\
\hline 6) How likely SPIKES training will change your future practices in BBN? & $0(-)$ & $1(2.7)$ & $36(97.3)$ \\
\hline 7) Was SPIKES training a good use of your time? & $0(-)$ & $2(5.4)$ & $35(94.6)$ \\
\hline 8) Please rate the overall value of SPIKES training & $0(-)$ & $0(-)$ & $37(100)$ \\
\hline
\end{tabular}

Abbreviations: BBN, break(ing) bad news; n, number of subjects. 
Table 2 SPIKES evaluations

\begin{tabular}{|c|c|c|c|c|c|c|}
\hline Resident & Gender & Age & $\begin{array}{l}\text { Residency } \\
\text { year }\end{array}$ & $\begin{array}{l}\text { Previous } \\
\text { Summative } \\
\text { Simulation }\end{array}$ & $\begin{array}{l}\text { Previous } \\
\text { Formative } \\
\text { Simulation }\end{array}$ & $\begin{array}{l}\text { Previous BBN } \\
\text { training }\end{array}$ \\
\hline \#5 Obst & $\mathrm{M}$ & 25 & $\mathrm{Y} 2$ & Yes & Yes & Yes \\
\hline \#7 Obst & $M$ & 30 & $\mathrm{Y4}$ & Yes & No & No \\
\hline \#9 Obst & $\mathrm{F}$ & 29 & Y4 & Yes & Yes & Yes \\
\hline \#18 Obst & $\mathrm{F}$ & 26 & $\mathrm{Y} 1$ & Yes & Yes & No \\
\hline$\# 21$ Obst & $\mathrm{F}$ & 24 & $\mathrm{Y} 1$ & Yes & Yes & No \\
\hline \#23 Obst & $\mathrm{F}$ & 25 & $\mathrm{Y1}$ & Yes & Yes & No \\
\hline \#3 Ped & $M$ & 27 & $\mathrm{Y} 2$ & Yes & Yes & No \\
\hline \#8 Ped & $\mathrm{F}$ & 28 & $\mathrm{Y} 1$ & Yes & No & No \\
\hline$\# 11$ Ped & $\mathrm{F}$ & 24 & $\mathrm{Y1}$ & Yes & Yes & Yes \\
\hline$\# 15$ Ped & $\mathrm{F}$ & 27 & $\mathrm{Y} 2$ & Yes & Yes & No \\
\hline \#17 Ped & $M$ & 24 & $\mathrm{Y} 2$ & Yes & No & No \\
\hline \#20 Ped & $\mathrm{F}$ & 25 & $\mathrm{Y1}$ & Yes & Yes & No \\
\hline \#23 Ped & $\bar{F}$ & 29 & $\mathrm{Y} 2$ & Yes & No & No \\
\hline$\# 25$ Ped & $\mathrm{F}$ & 26 & $\mathrm{Y} 2$ & Yes & Yes & No \\
\hline \#27 Ped & $\mathrm{F}$ & 28 & Y1 & Yes & Yes & No \\
\hline \#28 Ped & $\bar{F}$ & 26 & $\mathrm{Y1}$ & Yes & Yes & No \\
\hline \#2 Ped C & $\bar{F}$ & 28 & $\mathrm{Y3}$ & Yes & No & No \\
\hline \#16 Ped C & $\mathrm{F}$ & 31 & $\mathrm{Y4}$ & Yes & Yes & No \\
\hline \#21 Ped C & $\mathrm{F}$ & 25 & $\mathrm{Y1}$ & Yes & Yes & No \\
\hline \#26 Ped C & $\mathrm{F}$ & 25 & $\mathrm{Y} 2$ & Yes & Yes & No \\
\hline
\end{tabular}

Abbreviations: C, control; Obst, obstetrics; Ped, pediatrics.

\section{Medical Education and Communicating Bad News}

Many residents commented on how technical knowledge is prioritized during their training and the same value is not attributed to communicating with patients. Many of these residents regret the lack of training to deal with such difficult situations that are frequent in their everyday practice in a tertiary hospital. They recognize the need for specific training directed to improve doctor-patient communication.

"It is hardly taught during medical training or residency but it is very frequent in clinical practice" (\#26 Ped)

"It was really important to go through a training like this because at medical school we do not have this preparation or the notion of its importance...sometimes it is...or always... even more important than technical skills" (\#11 Ped)

"Only with training we can build skills and gain confidence to communicate bad news" (\# 9 Obst)

The majority suggested that training programs like this one should be incorporated in the curriculum of medical schools and residency programs as mandatory, with enough time allocated to it, independently from the area of speciali- zation. Many noticed that only with training they might acquire skills and gain confidence. Some mentioned that the experience of participating in the training program will guide their future practices.

"Should be taught to all residents, independently from the specialization" (\#23 Obst)

"It should be incorporated in the medical school programs and even in the residency programs" (\#23 Ped)

"It already helped me and will help me to guide my future encounters" (\#21 Ped)

\section{Doctors' Feelings and Relationship with the Patients}

In their majority, residents recognized that communicating bad news is one of the most difficult activities in medical practice. Many commented about how the training allowed them to acquire a broader perspective of patients' needs. A good part of them wrote that the training helped better understand the patient and themselves. One resident wrote that training helped to alleviate the guilt of transmitting bad news. Many participants noticed increased comfort and confidence in breaking bad news to 
patients after training. Others wrote that training helped them deal with their insecurity and anxiety in difficult situations.

"...of all the medical practices, this is one of the most difficult." (\# 3 Ped)

"It improved a lot: It helped lift up the feelings of guilt when communicating bad news" (\#18 Obst)

“...mainly [it improved] our perceptions regarding patients feelings" (\#7 Obst)

"It was remarkable! It helped me to comfort [the patient] when breaking bad news" (\#21 Ped C)

“...it also increased doctoŕs comfort, bringing less anxiety and more security in his/her work" (\#25 Ped)

\section{Discussion}

Recently, many publications about bad news communication in the context of perinatology have analyzed the communication pattern of health professionals, its deficits and its impact on parents. ${ }^{3,25-28}$ In their study, Tobler et al ${ }^{14}$ used, as simulated patients, parents who in real life had experienced receiving bad news about their child. These parents brought their perspectives to the training, expanding health professionals' understanding about their needs and expectations when facing this situation. A series of articles being published since 2011 on the journal Lancet, dedicated to reducing stillbirth in the world by 2030, suggested the need to understand parent's perspectives. ${ }^{29}$ Some highlight the health team unpreparedness and the impact of the care provided on parents. ${ }^{30,31}$ All these articles emphasized the urgency for specific training so that health professionals could better attend the needs of parents facing perinatal loss. Training would help prevent emotional damage for both, parents and professionals.

According to Orgel et al, ${ }^{16}$ teaching communication skills in medical practice is not prioritized, although it should rank higher in the list of importance. They "remain lost in the crushing patient load, the ever-increased volume of pathologies and treatments to learn and in the overburdened medical systems of academic medical centers." ${ }^{16}$ Thus, for developing communication skills, residents are usually limited to observing faculty or senior colleagues, who are mostly unprepared to teach the principles and do not have the knowledge or the techniques to do so, thus perpetuating errors with their toll on the patients. Bowyer et $\mathrm{al}^{11}$ called it the see one do one approach. Most residents in our study reported no formal training. Indeed, training in such complex abilities require time and resources not always available or prioritized. ${ }^{22}$

Our study offered a training opportunity to teach complex and learnable abilities necessary for medical practice as suggested by studies about communication skills. ${ }^{1,32}$ Reed et al $^{33}$ concluded that once learned, these abilities are retained over time. Most of the residents who evaluated our training stated that they would modify their future practices.
The volunteer residents in our study seem to have taken this training opportunity to fill the existing gaps in their programs. Their written comments pointed to the need for similar training activities along their residency programs. They would like to see more opportunities for training and discussions in such difficult themes to improve their perceptions about themselves and about patients' needs. All comments pointed in the direction of the SPIKES training bringing tools to help residents. They reported that it facilitated the development of needed skills; it was reassuring; it gave them more security. These comments confirmed Rosembaum et $\mathrm{al}^{34}$ and Meyer et $\mathrm{al}^{32}$ results. In their two different studies, they demonstrated that training in BBN for residents was highly valued, amplified their abilities to communicate, increased their comfort levels and decreased anxiety, favoring doctor-patient relationships.

One of the strengths of our training was using a mix of active and reflexive methods well known to promote adult learning in medical education. ${ }^{35}$ In our study, training was based on the experience of simulation, SP feedback, video review of residents' own videos and peer discussions. Rosembaum et $\mathrm{al}^{34}$ in a systematic review, concluded that these methodologies are recognized as effective in learning communication skills. The authors commented on their surprise to learn that in many of the reviewed studies the participants requested more training. Corroborating these findings, in our study, more than half of the control group returned to the SPIKES training after completing their participation in the research despite their busy schedules.

Karkowsky et $\mathrm{al}^{36}$ suggested the need to have well-defined research goals of what is being measured when using simulation. In our study, we intended to provide the opportunity for residents to experience a mother's emotional reactions, as well as their own, when news of her fetal death or an imminent death of her newborn is communicated. Simulation provided, as the above study reinforced, a secured and protected setting for both, residents and simulated parents. Feedback from the SP enhanced the experience. Residents heard the "mother's" perspective of how she felt, what she expected from the doctor, which attitudes were appreciated and which ones were felt inadequate. Her comments were very similar to the ones described by Peters et $\mathrm{al}^{13}$ in their systematic review of qualitative articles about the impact of a stillbirth diagnosis on parents.

The residents in our study had multiple opportunities to better understand and review their skills and limitations: practicing, receiving feedback from the SP, reflecting on their personal experiences and reviewing their own video. Similarly to what was reported in the work of Peters et al, ${ }^{13}$ they became aware of what it takes to break bad news in a sensitive way with competence. They came to realize this is a key factor to minimize the parents' emotional suffering. The active methods used during the project, including reviewing their own videos, made it interesting, practical and meaningful to residents. "It was remarkable," wrote one resident. "It helped and oriented how to deal with a delicate moment in our careers" wrote another.

Our project demonstrated that residents are interested, need and are aware of the benefits of training in BBN. They 
are willing to discuss and reflect on the theme. They want it to be more frequent and included in the curriculum. They seriously participated in the training even after hours, following a long working day. Training brought in tools to facilitate the development of communication skills, with security. Maybe longer and more frequent training programs might reduce their discomfort and increase their skills in responding to the patients' emotions. Nevertheless, a certain dose of discomfort is inevitable in situations that are too contrary to everybody's expectations: parents, families and health care providers. It is part of what make us humans: the impossibility of having control over every situation in life.

A limitation in our study is the fact that the residents who participated might have been the ones more motivated. A selection bias might have occurred. We do not know the evaluations of the ones who did not volunteer in the project. Not all participants wrote comments about the training: the answers we received might be biased toward a more favorable evaluation of the activities. Due to budget constraints, we did not have the father present in our simulations, despite recommendations that both parents should be together so grieving would start synchronized. ${ }^{19}$ To minimize this limitation, our cases were built around single mothers with no partners.

Organizing a training program like this one requires financial resources, time availability, teamwork, institutional support and experts in medical education, in active methodologies and in bereavement techniques. All these are limitations to implement and maintain training in the long term. Nevertheless, this evaluation helped to demonstrate the need, interest and urgency in incorporating bad news training in medical residency programs based on the best evidence available.

\section{Conclusions}

Residents evaluated training as a good support to systematize and to encourage reflections on the process of communicating bad news in perinatology. Residents suggest formal training must be included in their program's curricula.

\section{Contributions \\ Setubal MSV, Gonçalves AV, Rocha SR and Amaral EM have participated in the project concept, analysis and inter- pretation of data, drafting and revising of the manuscript and they have approved the manuscript as submitted.}

\section{Conflict of Interest}

Authors declare no conflict of interest.

\section{Acknowledgments}

The Coordination for the Improvement of Higher Education Personnel (CAPES) at the Brazilian Ministry of Education contributed with the first author's doctoral scholarship. This project had financial support from Fundação de Amparo à Pesquisa do Estado de São Paulo (FAPESP)
(Foundation for the Advance of Research in São Paulo State), grant \# 2013/24185-0. The Faculdade de Ciências Médicas da Universidade Estadual de Campinas (FCM UNICAMP) and the Simulation Laboratory offered logistic support for recording the simulations and indicating the actresses and technicians involved in the project.

\section{References}

1 Fallowfield L, Jenkins V. Communicating sad, bad, and difficult news in medicine. Lancet 2004;363(9405):312-319

2 Jacques AP, Adkins EJ, Knepel S, Boulger C, Miller J, Bahner DP. Educating the delivery of bad news in medicine: Preceptorship versus simulation. Int J Crit Illn Inj Sci 2011;1(02):121-124

3 Henley A, Schott J. The death of a baby before, during or shortly after birth: good practice from the parents' perspective. Semin Fetal Neonatal Med 2008;13(05):325-328

4 Peters MD, Lisy K, Riitano D, Jordan Z, Aromataris E. Caring for families experiencing stillbirth: Evidence-based guidance for maternity care providers. Women Birth 2015;28(04):272-278

5 Prinds C, Hvidt NC, Mogensen O, Buus N. Making existential meaning in transition to motherhood-a scoping review. Midwifery 2014;30(06):733-741

6 Lisy K, Peters MD, Riitano D, Jordan Z, Aromataris E. Provision of meaningful care at diagnosis, birth, and after stillbirth: A qualitative synthesis of parent's experiences. Birth 2016;43(01):6-19

7 Sullivan AM, Warren AG, Lakoma MD, Liaw KR, Hwang D, Block SD. End-of-life care in the curriculum: a national study of medical education deans. Acad Med 2004;79(08):760-768

8 Gough JK, Frydenberg AR, Donath SK, Marks MM. Simulated parents: developing paediatric trainees' skills in giving bad news. J Paediatr Child Health 2009;45(03):133-138

9 Saviani-Zeoti F, Petean EB. Breaking bad news: doctors' feelings and behaviors. Span J Psychol 2007;10(02):380-387

10 Ministério da Educação. Residência Médica em Pediatria com Duração de Três Anos Áreas de Atuação Pediátrica com Duração de Dois Anos: Proposta da Sociedade Brasileira de Pediatria. http://portal. mec.gov.br/index.php?option=com_docman\&view=download\&alias=6532-pediatria-sesu-rm\&category_slug=agosto-2010-pdf\&Itemid=30192. Accessed February 24, 2016

11 Bowyer MW, Hanson JL, Pimentel EA, et al. Teaching breaking bad news using mixed reality simulation. J Surg Res 2010;159(01): 462-467

12 Vail L, Sandhu H, Fisher J, Cooke H, Dale J, Barnett M. Hospital consultants breaking bad news with simulated patients: an analysis of communication using the Roter Interaction Analysis System. Patient Educ Couns 2011;83(02):185-194

13 Peters MD, Lisy K, Riitano D, Jordan Z, Aromataris E. Providing meaningful care for families experiencing stillbirth: a metasynthesis of qualitative evidence. J Perinatol 2016;36(01):3-9

14 Tobler K, Grant E, Marczinski C. Evaluation of the impact of a simulation-enhanced breaking bad news workshop in pediatrics. Simul Healthc 2014;9(04):213-219

15 Baile WF, Buckman R, Lenzi R, Glober G, Beale EA, Kudelka AP. SPIKES-A six-step protocol for delivering bad news: application to the patient with cancer. Oncologist 2000;5(04):302-311

16 Orgel E, McCarter R, Jacobs S. A failing medical educational model: a self-assessment by physicians at all levels of training of ability and comfort to deliver bad news. J Palliat Med 2010;13(06):677-683

17 Buckman R, Kason Y. How to Break Bad News: A Guide for Health Care Professionals. Baltimore, MD: Johns Hopkins University Press; 1992

18 Baile WF, Buckman R, Schapira L, Parker PA. Breaking bad news: more than just guidelines. J Clin Oncol 2006;24(19):3217, author reply 3217-3218 
19 Defey D, Diaz Rossello JL, Friedler R, Nuñez M, Terra C. Duelo por un Niño que Muere antes de Nacer: Vivencias de los Padres y del Equipo de Salud. 3a ed. Montevideo: Gnosos; 1997

20 Kelley MC, Trinidad SB. Silent loss and the clinical encounter: Parents' and physicians' experiences of stillbirth-a qualitative analysis. BMC Pregnancy Childbirth 2012;12:137

21 Hammoud MM, Morgan HK, Edwards ME, Lyon JA, White C. Is video review of patient encounters an effective tool for medical student learning? A review of the literature. Adv Med Educ Pract 2012;3:19-30

22 Daetwyler CJ, Cohen DG, Gracely E, Novack DH. eLearning to enhance physician patient communication: a pilot test of "doc. com" and "WebEncounter" in teaching bad news delivery. Med Teach 2010;32(09):e381-e390

23 Turato ER. Tratado da Metodologia da Pesquisa Clínico-Qualitativa: Construção Teórico-Epistemológica, Discussão Comparada $e$ Aplicação nas Áreas da Saúde e Humanas. Petrópolis: Vozes; 2003

24 Gale NK, Heath G, Cameron E, Rashid S, Redwood S. Using the framework method for the analysis of qualitative data in multidisciplinary health research. BMC Med Res Methodol 2013;13:117

25 Meert KL, Eggly S, Pollack M, et al; National Institute of Child Health and Human Development Collaborative Pediatric Critical Care Research Network. Parents' perspectives on physician-parent communication near the time of a child's death in the pediatric intensive care unit. Pediatr Crit Care Med 2008;9(01):2-7

26 Kingdon C, O'Donnell E, Givens J, Turner M. The role of healthcare professionals in encouraging parents to see and hold their stillborn child: A meta-synthesis of qualitative studies. PLoS One 2015;10(07):e0130059
27 Ellis A, Chebsey C, Storey C, et al. Systematic review to understand and improve care after stillbirth: a review of parents' and healthcare professionals' experiences. BMC Pregnancy Childbirth 2016;16:16

28 Nuzum D, Meaney S, O'Donoghue K. The impact of stillbirth on consultant obstetrician gynaecologists: a qualitative study. BJOG 2014;121(08):1020-1028

29 Stillbirth 2011: The Lancet Series on Stillbirth. Lancet. 2011. http:// www.thelancet.com/series/stillbirth. Accessed February 16, 2016

30 Scott J. Stillbirths: breaking the silence of a hidden grief. Lancet 2011;377(9775):1386-1388

31 Homer CSE, Malata A, ten Hoope-Bender P. Supporting women, families, and care providers after stillbirths. Lancet 2016;387 (10018):516-517

32 Meyer EC, Sellers DE, Browning DM, McGuffie K, Solomon MZ, Truog RD. Difficult conversations: improving communication skills and relational abilities in health care. Pediatr Crit Care Med 2009;10(03):352-359

33 Reed S, Kassis K, Nagel R, Verbeck N, Mahan JD, Shell R. Breaking bad news is a teachable skill in pediatric residents: A feasibility study of an educational intervention. Patient Educ Couns 2015; 98(06):748-752

34 Rosenbaum ME, Ferguson KJ, Lobas JG. Teaching medical students and residents skills for delivering bad news: a review of strategies. Acad Med 2004;79(02):107-117

35 Reed S, Shell R, Kassis K, et al. Applying adult learning practices in medical education. Curr Probl Pediatr Adolesc Health Care 2014; 44(06):170-181

36 Karkowsky CE, Chazotte C. Simulation: improving communication with patients. Semin Perinatol 2013;37(03):157-160 